\title{
Nowa metoda interpretacji przestrzeni porowej na podstawie łączenia badań porozymetrii rtęciowej i adsorpcji azotu na przykładzie wybranych łupków menilitowych
}

\author{
Novel method of pore space interpretation based on joint Mercury Intrusion Porosimetry \\ and Nitrogen Adsorption of the selected Menilite Shales
}

\author{
Lidia Dudek \\ Instytut Nafty i Gazu - Państwowy Instytut Badawczy
}

\begin{abstract}
STRESZCZENIE: W artykule przedstawiono nowe podejście do interpretacji charakterystyki przestrzeni porowej, polegające na połączeniu pochodnych różnic objętości porowych - wyników porozymetrii rtęciowej i adsorpcji azotu na wspólnej skali, bez stosowania jakichkolwiek sztucznych przesunięć danych. To nowe podejście zastosowano wykorzystując wyniki pomiarów próbek łupków menilitowych pobranych z powierzchni terenu. Jest ono oparte na przyjętym założeniu, że w zakresie dowolnie wybranych średnic porowych istniejąca objętość porowa jest niezależna od użytego typu cieczy niezwilżającej (rtęć, ciekły azot, ciekły argon itp.). Jakiekolwiek różnice pomiarowe wynikające z tych dwóch pomiarów są konsekwencją mechanicznego pękania ścianek porów pod wpływem wysokich ciśnień rtęci lub też ich odkształceń elastycznych i\lub plastycznych oraz innych interakcji pomiędzy materiałem ścianek porów a zastosowaną cieczą niezwilżającą. Znaczące populacje porów w łupkach są zbyt małe, aby mierzyć je tylko za pomocą MICP (ang. Mercury Injection Capillary Pressure), co wyjaśniałoby niedoszacowanie całkowitej połączonej objętości porowej. Dlatego też do jej określenia zastosowano uzupełniającą metodę adsorpcji azotu. Struktura porowa próbek łupków menilitowych wygrzanych w $105^{\circ} \mathrm{C}$ była mierzona metodą porozymetrii rtęciowej w temperaturze otoczenia oraz metodą adsorpcji azotu w temperaturze wrzenia ciekłego azotu $-195,8^{\circ} \mathrm{C}$. Rozkłady pochodnych objętości względem średnicy porów otrzymanych z tych dwóch uzupełniających się metod zostały przedstawione w postaci wykresów zależności $d V / d D$. Na podstawie badań porozymetrycznych i piknometrii helowej obliczono porowatość całkowitą i otwartą, co pozwoliło na scharakteryzowanie własności filtracyjnych próbek skał. Na podstawie badań adsorpcyjnych obliczono powierzchnię właściwą BET, rozkład wielkości porów i zajmowaną przez nie objętość.
\end{abstract}

Słowa kluczowe: łupki menilitowe, adsorpcja, desorpcja, porozymetria rtęciowa, powierzchnia właściwa, temperatura wygrzewania.

\begin{abstract}
In this paper, a new approach has been shown for the interpretation of the pore space characteristics, consisting in combining pore space volumetric fractional derivatives of mercury intrusion and nitrogen adsorption on the same scale without using any artificial data transformation. This new approach was shown using obtained results of measurements of surface Menilite Shales. It is based on the assumption that for any selected pore diameters, the existing pore space volume is independent of the applied non-wetting liquid agent (mercury, liquid nitrogen, liquid argon etc.). Any recorded differences of these two methods are due to cracking of pore walls under high mercury pressure or their elastic and/or plastic deformations and other interactions between pore building material and the non-wetting liquid used. Significant populations of pores in shales are too small to be measured using only MICP (Mercury Injection Capillary Pressure), which would explain the underestimation of the total porous space. Therefore, for its proper estimation, the complementary method of nitrogen adsorption has been used. The porous structure of Menilite Shale samples preheated at $105^{\circ} \mathrm{C}$ was measured using the mercury intrusion method MICP at ambient temperature and using nitrogen adsorption at its boiling point temperature of $-195.8^{\circ} \mathrm{C}$. Volumetric fractional derivatives of pore diameters obtained by these 2 different complementary methods were shown in the form of graphs $d V / d D$. Based on the porosimetric and helium pycnometric tests both bulk and open porosity was calculated, which allowed to characterise the filtration properties of rock samples. Based on the adsorption testing, the specific surface BET was calculated, as well as the pore size distribution and its total porous volume.
\end{abstract}

Key words: Menilite Shale, adsorption, desorption, Mercury Injection Capillary Pressure, specific surface area, heating temperature.

Autor do korespondencji: L. Dudek, e-mail: lidia.dudek@inig.pl

Artykuł nadesłano do Redakcji: 05.12.2019 r. Zatwierdzono do druku: 23.04.2020 r. 


\section{Wprowadzenie}

W geologii naftowej scharakteryzowanie i opisanie fizycznych właściwości przestrzeni porowej polega na poprawnym określeniu możliwości transportu i magazynowania płynów złożowych przez ośrodek filtracyjny. Przestrzeń porowa danej próbki skalnej to mikrokapilarny ośrodek złożony z dużej liczby nieregularnych w kształcie i ułożeniu kapilar, który może być wypełniony płynami złożowymi. Jednym z ważniejszych aspektów takiego medium porowego jest porowatość i rozkład wielkości porów (ang. pore size distribution), które wpływają na większość charakterystyk zachowania się tych mediów, np. charakterystykę sprężystą i mechaniczną, ruch i przepływ płynów. Badanie i parametryzację przestrzeni porowej uzyskuje się pomiarami krzywych ciśnień kapilarnych, wykorzystując zależność wielkości ciśnienia kapilarnego od wielkości promienia, kształtu porów i sieci połączeń między porami o różnych promieniach. W większości przypadków do analizy przestrzeni porowej stosowana jest porozymetria rtęciowa. Obecne ograniczenie oprzyrządowania dla MICP (60 000 psi) nie pozwala teoretycznie mierzyć porów mniejszych niż 3,6 nm (Kuila i Prasad, 2013), lecz nawet pory o średnicy powyżej tej wartości mogą być błędnie zinterpretowane ze względu na deformację przestrzeni porowej pod wpływem wysokich ciśnień roboczych rtęci. Z uwagi na niedoszacowanie całkowitej połączonej objętości porowej z porozymetrii rtęciowej stosuje się pomiary adsorpcji różnych gazów, np. azotu, argonu czy metanu. Należy mieć na uwadze, że zatłaczanie rtęci do próbki pod bardzo wysokimi ciśnieniami ma wpływ na ściśliwość struktury skały, możliwość pękania ścianek porów i otwierania zamkniętych porów oraz będzie wpływać na dane gromadzone przy tak wysokich ciśnieniach. Stąd z pomocą do badania bardzo małych porów, w przedziale od 0,3 nm do $200 \mathrm{~nm}$, przychodzi adsorpcja. Połączenie zatłaczania rtęci i adsorpcji azotu daje informacje o całej strukturze porowej. Jednakże należy pamiętać, że azot i rtęć rejestrują struktury porowe w odmienny sposób. Zatłaczanie rtęci do struktury porowej jest regulowane przez przewężenia porów, tzw. gardziele, podczas gdy zjawisko adsorpcji jest kontrolowane przez powierzchnię porów. Pomimo różnych fizycznych zasad, na których oparte są te dwie metody, ich wspólną cechą jest stopniowe ustalanie przyrostów objętości porów i przypisywanie ich do poszczególnych przedziałów szerokości porów. Dla każdej struktury porowej w zakresie wybranych średnic porowych objętościowa ilość cieczy niezwilżającej wypełniająca te pory powinna być identyczna bez względu na użytą ciecz (rtęć, ciekły azot, ciekły metan, ciekły argon itp.), a zaistniałe różnice pomiarowe są doskonałym źródłem informacji o właściwościach fizycznych i chemicznych tej struktury porowej. $Z$ tego względu tak ciekawym zagadnieniem jest połączenie danych z tych dwóch technik, dostarczające uzupełniających się informacji o strukturze porowej każdego medium porowego, w tym przypadku próbek łupków menilitowych pobranych z powierzchni terenu.

\section{Techniki badawcze i materiały}

\section{Porozymetria rteciowa}

Metodą powszechnie stosowaną do badań wszelkiego rodzaju materiałów porowatych jest porozymetria rtęciowa. Rtęć, jako ciecz niezwilżająca, intruduje w przestrzeń porową pod założonym ciśnieniem. Podczas wnikania rtęci w przestrzeń porową rejestrowana jest, w postaci krzywej, objętość rtęci, jaka została wtłoczona do próbki dla danego ciśnienia - to tzw. krzywa intruzji. Po osiągnięciu maksymalnego ciśnienia następuje spadek ciśnienia i rejestrowana jest krzywa osuszania, tzw. krzywa ekstruzji. Kształt krzywej wykreślonej dla malejących ciśnień stanowi podstawowe źródło informacji o wielkości odstępstwa realnej przestrzeni porowej od modelu walcowego. Krzywe intruzji i ekstruzji mają najczęściej odmienny przebieg, co określane jest jako efekt histerezy. Na podstawie tego efektu można obliczyć stosunek porów do przewężeń łączących pory. Porozymetria rtęciowa pozwala na obliczenie porowatości efektywnej, jednak nie uwzględnia porowatości zamkniętej, ponieważ jest ona niedostępna dla wtłaczanej rtęci. Analiza wyników badań otrzymanych z porozymetru rtęciowego AutoPore IV 9500 polega na wyliczeniu i zinterpretowaniu szeregu wielkości obliczonych z krzywych ciśnień kapilarnych oraz na analizie kształtu krzywych ciśnień kapilarnych.

Dla potrzeb niniejszego artykułu analiza porozymetryczna została wykonana w zakresie ciśnień 0,5-60 000 psi na próbkach łupków menilitowych. Obliczenia przeprowadzono automatycznie dla modelu cylindrów kapilarnych. Otrzymano krzywą kumulacyjną rozkładu średnic porów oraz wartości porowatości efektywnej odpowiadającej objętości rtęci, która wmigrowała do przestrzeni porowej. Parametryzacji przestrzeni porowej dokonano za pomocą pomiarów krzywych ciśnień kapilarnych. Wykorzystano zależność wielkości ciśnienia kapilarnego od wielkości promienia, kształtu porów i sieci połączeń między porami o różnych promieniach. Zależność tę przedstawia równanie Washbourna:

$$
\Delta p=-\frac{2 \gamma \cos \theta}{r}
$$

gdzie:

$r$ - promień porów,

$\gamma$ - napięcie powierzchniowe rtęci,

$\Theta$ - graniczny kąt zwilżania,

$\Delta p$ - różnica ciśnienia rtęci i ciśnienia gazu w porach $(\mathrm{p} 1-\mathrm{p} 0)$. 
Wyniki badań porozymetrycznych przedstawiono tabelarycznie w postaci udziału procentowego porów w próbce w odniesieniu do średnic porów (tab. 1).

\section{Pomiary adsorpcyjne}

Pomiary adsorpcyjne na skałach formacji łupków menilitowych wykonano za pomocą aparatu Tristar II 3020. Badania adsorpcji gazu $\left(\mathrm{N}_{2}\right)$ przeprowadzono w temperaturze ciekłego azotu $-195,8^{\circ} \mathrm{C}$. Rozdrobnione próbki, o masie poniżej 1 grama, poddano suszeniu w przedmuchu suchym azotem, w zaprogramowanym piętnastogodzinnym cyklu początkowo narastającej temperatury $10^{\circ} \mathrm{C} /$ minutę. Finalnie osiągnięto temperaturę $105^{\circ} \mathrm{C}$. Procedura wygrzewania została wykonana na aparacie SmartPrep, który jest częścią aparatu Tristar 3020 do badań adsorpcyjnych (Such et al., 2017). Suszenie i odgazowanie próbek miało na celu usunięcie z przestrzeni porowej wilgoci, resztek solanki i gazu w celu eliminacji zjawiska konkurowania analitu z płynami złożowymi o miejsca aktywne na powierzchni sorbentu (Cicha-Szot et al., 2015). Następnie próbkę chłodzono do temperatury pokojowej, również w przedmuchu suchym gazem (azotem). Tak przygotowaną próbkę dokładnie ważono zarówno przed suszeniem, jak i po, a następnie umieszczano w układzie pomiarowym urządzenia Tristar II 3020, wewnątrz tuby pomiarowej, gdzie po kilkukrotnym przepłukaniu jej helem wytwarzano próżnię. Kolejno probówkę z próbką zanurzano w ciekłym azocie, po czym w zautomatyzowanym trybie przeprowadzano procedurę pomiarowo-analityczną. Poprzez zmianę warunków bezwymiarowego ciśnienia względnego $\left(p / p_{0}\right)$ od 0,05 do 1 otrzymywano punkty pomiarowe dla wybranych ciśnień względnych, uzyskując pełen przebieg izotermy adsorpcji. Izotermę następnie przeliczano przez wybrany model BET (Brunauer et al., 1938) oraz BJH (Barrett et al., 1951) z krzywej adsorpcji, używając funkcji statystycznej grubości warstwy adsorpcyjnej $t\left(p / p_{0}\right)$ w postaci równania Halseya (Halsey, 1948) z zastosowaniem korekcji Faassa (Faass, 1981) w celu uzyskania danych między innymi: powierzchni właściwej i funkcji rozkładu objętości porów oraz pochodnej objętości porów względem ich średnicy $d V / d D$.

\section{Materiały}

Próbki skał, dla których wybrane analizy przedstawiono w niniejszym artykule, reprezentowane były przez łupki menilitowe, pobrane z odsłonięć karpackich. Do badania użyto 24 próbek powierzchniowych, które zostały rozdrobnione ręcznie za pomocą moździerza i przesiane przez sito $0,5-1 \mathrm{~mm}$.
Następnie wysuszono je w temperaturze $105^{\circ} \mathrm{C}$. W celu uniknięcia błędów i lepszej korelacji, wynikającej z połączenia pomiarów porozymetrii rtęciowej i adsorpcji azotu, pomiary wykonywano na tych samych fragmentach skał.

\section{Wyniki badań oraz ich dyskusja}

Izotermy adsorpcji najczęściej przedstawia się w postaci zależności objętości zaadsorbowanego gazu na gram próbki (objętość ta podawana jest na osi rzędnych w warunkach STP - czyli standardowej temperatury oraz ciśnienia) od opisujących oś odciętych bezwymiarowych jednostek, ciśnień względnych $p / p_{0}$, gdzie $p$ jest bezwzględnym ciśnieniem równowagi, a $p_{0}$ ciśnieniem pary nasyconej adsorbatu (Dudek, 2016, 2019). W pracy przedstawiono tabelarycznie (tab. 1) zestawienie wartości BET, które wahają się od $0,6310 \mathrm{~m}^{2} / \mathrm{g}$ w rejonie Rudawki Rymanowskiej (próbka 1) do 30,0390 m²/g w rejonie Dynowa (próbka 14). W tabeli 1 zamieszczono również wyniki z badań porozymetrycznych z procentowym udziałem porów dla poszczególnych próbek. Najwięcej najmniejszych porów $(0,01-0,005 \mu \mathrm{m})$ posiada próbka $20 \mathrm{z}$ Tarnawki - 32,5\%, a najmniej próbka 8 z Habkowiec - 0,2\%. Najwięcej porów w zakresie 10-1,0 $\mu \mathrm{m}$ posiada próbka $6 \mathrm{z}$ rejonu Strzebowisk 32,8\%, a najmniej próbka 3 z Wernejówki - 7,7\%. Największą porowatością otwartą, wynoszącą 48,26\%, charakteryzuje się próbka 18 z Woli Węgierskiej, ma więc najlepsze warunki transportu mediów złożowych. Najgorsze warunki transportu cechują próbkę 5 z Jabłonek, w przypadku której porowatość otwarta wynosi 2,37\%.

\section{Analiza wyników z porozymetrii rtęciowej i adsorpcji azotem}

Wyniki łączenia porozymetrii rtęciowej z adsorpcją w szeregu różnych publikacjach (Dudek, 2016; Such et al., 2017) wyglądają typowo tak, jak przedstawiono na rysunku 1 dla wybranej próbki 13, lub bardziej korzystnie tak, jak przedstawiono na rysunku 2, gdyż oś rzędnych jest rosnąca od lewej strony do prawej.

Rysunek 2 przedstawia również rzeczywistą wartość danych kumulacyjnych adsorpcji, które są transferowane sztucznie w górę, dla punktu $0,1 \mu \mathrm{m}$ celem uzyskania wspólnego obrazu dla porozymetrii rtęciowej i adsorpcji, z którego jednakże można wyciągnąć tylko znacznie ograniczone wnioski. Bardziej skutecznym sposobem łączenia tych wykresów jest połączenie ich wartości pochodnych $d V / d D$, jak przedstawiono na rysunku 3 w skali logarytmicznej, a na rysunku 4 wybrany fragment w skali liniowej. 


\section{NAFTA-GAZ}

\begin{tabular}{|c|c|c|c|c|c|c|c|c|c|c|c|c|c|c|c|c|c|c|c|c|}
\hline \multirow{4}{*}{ 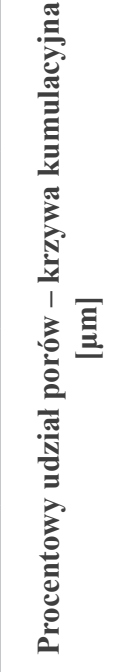 } & 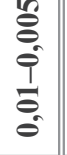 & $\begin{array}{c}m \\
\infty \\
\infty \\
-1\end{array}$ & \begin{tabular}{l}
0 \\
0 \\
\hdashline
\end{tabular} & $\begin{array}{ccc}0 \\
\tilde{n}^{2} & 1\end{array}$ & $\hat{m}$ & \begin{tabular}{l|l}
0 \\
0 \\
0
\end{tabular} & 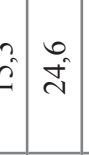 & \begin{tabular}{l|l}
2 & 1 \\
0 & 4
\end{tabular} & $\begin{array}{c}\sqrt{2} \\
n\end{array}$ & $\begin{array}{c}0 \\
i \\
m \\
m\end{array}$ & \begin{tabular}{l|l}
$\circ$ & 0 \\
$\circ$ & 0
\end{tabular} & \begin{tabular}{c|c|c}
$\infty_{\infty}^{2}$ & $\infty^{2}$ \\
-1
\end{tabular} & \begin{tabular}{l|l}
0 & $y$ \\
$i$ & $y$
\end{tabular} & $\because 2 \vec{r}$ & \begin{tabular}{l|l}
$n$ & 0 \\
$n$ & $n$
\end{tabular} & $\begin{array}{ll}2 & n \\
r & n\end{array}$ & $\begin{array}{l}n \\
0 \\
0\end{array}$ & 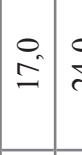 & \begin{tabular}{l|l} 
\\
$\stackrel{+}{+}$ & \\
\end{tabular} & $\overrightarrow{0}$ \\
\hline & $\begin{array}{l}\bar{E} \\
0 \\
\frac{1}{0} \\
0\end{array}$ & $\hat{m}$ & $\frac{\sigma_{0}}{\vec{n}}$ & $\sigma^{\circ}$ & \begin{tabular}{l|l}
$\dot{8}$ \\
$\dot{8}$
\end{tabular} & $\stackrel{n}{n} \stackrel{n}{\simeq}$ & 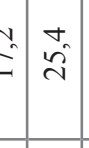 & $\vec{f}$ & તે & $\begin{array}{l}\hat{\delta} \\
\hat{\delta}\end{array}$ & \begin{tabular}{l|l}
$n$ \\
$f$ \\
$f$
\end{tabular} & \begin{tabular}{c|c}
0 & $\infty$ \\
$\dot{\delta}$ & $\infty$ \\
$\infty$ & $\infty$
\end{tabular} & 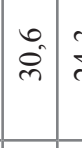 & \begin{tabular}{l|l}
$\stackrel{0}{+}$ \\
$\stackrel{d}{0}$
\end{tabular} & \begin{tabular}{l|l}
$\infty$ & 0 \\
$\infty$ & 7 \\
- & 7
\end{tabular} & \begin{tabular}{l|l}
0 & 0 \\
$\dot{\nabla}$ & $n$
\end{tabular} & $\begin{array}{c}n \\
\tilde{f}\end{array}$ & $\begin{array}{c}m \\
\dot{8}\end{array}$ & $\vec{m}$ & है \\
\hline & $\overrightarrow{\hat{I}}$ & 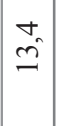 & $\stackrel{n}{=}$ & 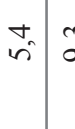 & $\begin{array}{c}m \\
a^{2} \\
\stackrel{n}{r}\end{array}$ & $\begin{array}{lll}n & \infty \\
2 & \infty \\
n & n\end{array}$ & 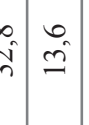 & हो & $\begin{array}{lll}0 & \text { m } \\
\text { f } & \sigma^{2}\end{array}$ & $\mid \begin{array}{ll}0 \\
0 \\
0\end{array}$ & $\stackrel{n}{=}$ & \begin{tabular}{l|l}
$\stackrel{+}{=}$ & $\stackrel{\vec{v}}{\vec{N}}$
\end{tabular} & $\begin{array}{l}m \\
\hat{n} \\
m\end{array}$ & \begin{tabular}{c|c}
$\infty$ \\
$\vec{f}$ & $m$ \\
$m$
\end{tabular} & $\overrightarrow{\dot{n}}$ & $\begin{array}{c}\text { mी } \\
m \\
\tilde{y}\end{array}$ & 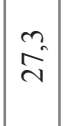 & $a^{2}$ & $\begin{array}{l}\infty \\
\text { ते }\end{array}$ & ¿̊ \\
\hline & $\begin{array}{l}\stackrel{\theta}{i} \\
\stackrel{i}{=}\end{array}$ & $\stackrel{\cong}{=}$ & $\begin{array}{c}m \\
\infty \\
\infty\end{array}$ & $\therefore$ & $\overrightarrow{0}$ & $\vec{m} \mid \begin{array}{ll}\infty \\
m\end{array}$ & $\begin{array}{l}0 \\
\hat{v} \\
\end{array}$ & \begin{tabular}{l|l}
0 & \\
$i$ &
\end{tabular} & 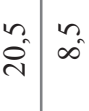 & $\hat{\tilde{\theta}}$ & 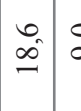 & \begin{tabular}{l|l}
$\therefore$ & $\alpha_{0}$
\end{tabular} & \begin{tabular}{|l|l}
$\infty$ & \\
\hdashline & \\
\hdashline
\end{tabular} & $\overrightarrow{\vec{v}} \mid \begin{array}{l}\vec{d} \\
\stackrel{i}{*}\end{array}$ & $\begin{array}{lll}0 & 1 \\
\infty & m\end{array}$ & $\hat{\stackrel{m}{ }} \stackrel{\infty}{=}$ & $\begin{array}{l}n \\
\hat{\imath}\end{array}$ & $\stackrel{n}{=}$ & $\begin{array}{l}\infty \\
n^{0} \\
\end{array}$ & $\vec{\imath}$ \\
\hline 吾 & $\dot{0}^{\circ}$ & $\mid$ & $\begin{array}{c}\vec{y} \\
\infty \\
\infty\end{array}$ & $\begin{array}{ll}\vec{n} \\
\vec{n}\end{array}$ & 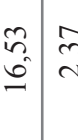 & 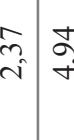 & 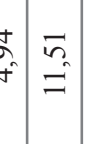 & \begin{tabular}{l|l}
2 & 5 \\
$\hat{\Xi}$ & 4
\end{tabular} & 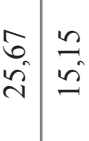 & $\stackrel{n}{\stackrel{n}{a}}$ & 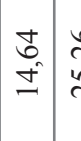 & 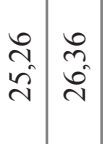 & \begin{tabular}{l|l}
$\infty$ & 0 \\
0 & 0 \\
$\tilde{m}$ &
\end{tabular} & \begin{tabular}{l|l}
$\overrightarrow{\vec{\Omega}}$ & $\widehat{\hat{\sigma}}$ \\
$\hat{\tilde{N}}$ & $\hat{0}$
\end{tabular} & 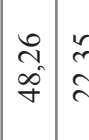 & 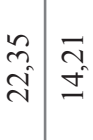 & in & 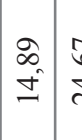 & $\begin{array}{l}\hat{b} \\
\dot{d}\end{array}$ & के \\
\hline 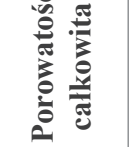 & $\dot{a}^{\circ}$ & $\begin{array}{l}\stackrel{2}{=} \\
=\end{array}$ & $\stackrel{\circ}{\circ}$ & 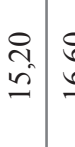 & 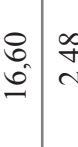 & 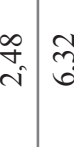 & 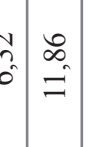 & \begin{tabular}{l|l}
$\hat{a}$ \\
$\hat{y}$
\end{tabular} & 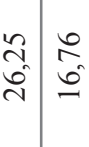 & $\begin{array}{l}\hat{a} \\
\stackrel{i}{c}\end{array}$ & \begin{tabular}{l|l} 
& 8 \\
\pm & 4
\end{tabular} & 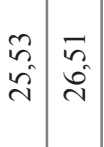 & \begin{tabular}{l|l}
$\hat{A}$ & $\vdots$ \\
$\dot{m}$ & $\delta$
\end{tabular} & \begin{tabular}{l|l}
0 & 0 \\
$\delta$ & 0 \\
$i$ & $\infty$ \\
\end{tabular} & 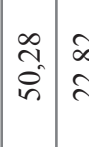 & 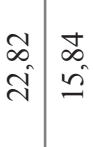 & \begin{tabular}{|l|} 
\\
$\infty$ \\
0 \\
6 \\
6
\end{tabular} & \begin{tabular}{l|l}
0 & $\vdots$ \\
$i$ &
\end{tabular} & $\begin{array}{l}\text { הે } \\
\text { â. }\end{array}$ & م. \\
\hline 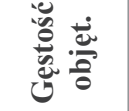 & 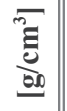 & $\underset{\vec{i}}{ \pm}$ & $\overrightarrow{\vec{i}}$ & 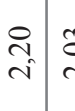 & \begin{tabular}{l|l}
0 & $\infty$ \\
$i$ & $n$ \\
$i$ & $n$
\end{tabular} & 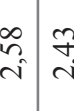 & $\begin{array}{l}\vec{f} \\
\vec{v} \\
\vec{i}\end{array}$ & \begin{tabular}{c|c}
$\hat{i}$ & $\delta$ \\
$\hat{i}$ &
\end{tabular} & 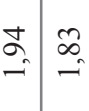 & $\hat{c} \begin{array}{c}\hat{i} \\
\hat{i}\end{array}$ & $\begin{array}{ll}\vec{\sim} & \\
\vec{i} & \end{array}$ & $\stackrel{尺}{\stackrel{\Xi}{=}}$ & $\stackrel{f}{-}$ & 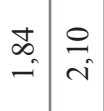 & 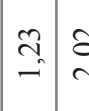 & \begin{tabular}{lll}
$\tilde{d}$ & \multirow{2}{c}{} \\
$i$ &
\end{tabular} & in & 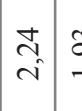 & $\hat{\sigma}$ & $\begin{array}{l}\text { in } \\
\text { in }\end{array}$ \\
\hline 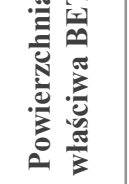 & $\begin{array}{l}\overrightarrow{500} \\
\vec{a} \\
\overrightarrow{\underline{B}}\end{array}$ & $\begin{array}{l}0 \\
0 \\
0\end{array}$ & $\begin{array}{l}\hat{a} \\
\dot{+}\end{array}$ & \begin{tabular}{l|l}
2 & 2 \\
$i$ & $\alpha$ \\
$i$ & 0
\end{tabular} & \begin{tabular}{c|c}
$\tilde{\infty}$ & $\mathcal{1}$ \\
$i$ & -
\end{tabular} & \begin{tabular}{l|l}
$\approx$ & 2 \\
$\approx$ & 0
\end{tabular} & $\hat{\sigma}=\bar{\sigma}$ & 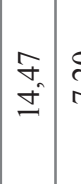 & 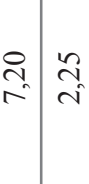 & $\begin{array}{l}0 \\
\because \\
\leftarrow\end{array}$ & $\stackrel{\infty}{m^{n}}$ & 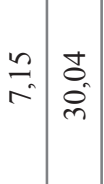 & $\underset{f}{q}$ & \begin{tabular}{c|c}
0 & $n$ \\
$m^{2}$ & 0 \\
$m$ & 0
\end{tabular} & 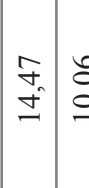 & \begin{tabular}{l|l}
0 & 0 \\
0 & $i$
\end{tabular} & $\mid \begin{array}{l}6 \\
0 \\
-1\end{array}$ & 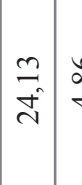 & $\begin{array}{l}\searrow \\
\infty \\
+\end{array}$ & $\begin{array}{l}0 \\
\varrho\end{array}$ \\
\hline 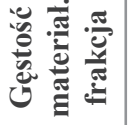 & \begin{tabular}{l|}
$\overline{\bar{g}}$ \\
$\bar{b}$
\end{tabular} & $\mid \begin{array}{l}\infty \\
0 \\
\hat{i} \\
\end{array}$ & $\begin{array}{l}\stackrel{9}{i} \\
i\end{array}$ & 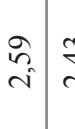 & 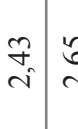 & \begin{tabular}{l|l} 
& $n$ \\
0 & $n$ \\
$i$ & $n$
\end{tabular} & 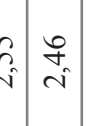 & \begin{tabular}{l|l}
$\vec{b}$ & $\overrightarrow{3}$ \\
$i$ & 0
\end{tabular} & \begin{tabular}{l|l}
$\vec{b}$ & $n$ \\
$i$ & $\vec{n}$
\end{tabular} & $\begin{array}{l}8 \\
8 \\
i\end{array}$ & 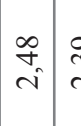 & $\begin{array}{ll}\vec{m} & \vec{F} \\
i & i\end{array}$ & \begin{tabular}{l|l}
$\hat{n}$ & $\bar{a}$ \\
$\hat{i}$ & 0
\end{tabular} & \begin{tabular}{l|l}
$\vec{m}$ & $\tilde{n}$ \\
$i$ & $i$
\end{tabular} & $\begin{array}{cc}\hat{m} & \varepsilon \\
i & 0\end{array}$ & \begin{tabular}{c|c}
8 & $t$ \\
$i$ & $i$
\end{tabular} & $\begin{array}{l}\infty \\
\hat{i} \\
c\end{array}$ & \begin{tabular}{c|c}
$\hat{b}$ & 1 \\
$i$ &
\end{tabular} & $\begin{array}{l}n \\
i \\
i\end{array}$ & i \\
\hline 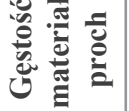 & $\begin{array}{l}\overline{\bar{g}} \\
\overline{\bar{g}} \\
\overline{\mathrm{g}}\end{array}$ & $\overrightarrow{\vec{F}}$ & $\begin{array}{l}q \\
i \\
i\end{array}$ & 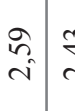 & 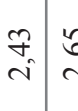 & 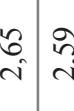 & $\begin{array}{r}\hat{f} \\
\hat{i} \\
\hat{i} \\
i \\
i\end{array}$ & \begin{tabular}{l|l}
$\vec{b}$ & 5 \\
$i$ & 0
\end{tabular} & 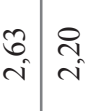 & $\begin{array}{l}8 \\
i \\
i\end{array}$ & $\begin{array}{c}\infty \\
\stackrel{c}{c}\end{array}$ & \begin{tabular}{l|l}
$\stackrel{q}{q}$ & $\bar{f}$ \\
$i$ & $i$
\end{tabular} & 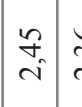 & \begin{tabular}{c|c}
0 & $\tilde{n}$ \\
$i$ & $i$ \\
$i$ & $i$
\end{tabular} & 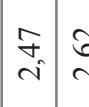 & \begin{tabular}{c|c}
$\mathbb{N}$ & $\infty$ \\
$i$ & 0 \\
$i$ & $i$
\end{tabular} & $\hat{i}$ & $\mid$\begin{tabular}{l|l}
$n$ & 0 \\
$i$ & 4 \\
$i$ & 0
\end{tabular} & $\begin{array}{l}\hat{n} \\
\text { i }\end{array}$ & $\hat{i}$ \\
\hline 之竞 & & -1 & $N$ & $m$ & \begin{tabular}{l|l} 
& in
\end{tabular} & in 0 & $0-1$ & \begin{tabular}{l|l}
$\infty$ & 0
\end{tabular} & a & $=$ & $\simeq 工$ & $\stackrel{\Xi}{ \pm}$ & $\because$ & $\because=$ & $\stackrel{\infty}{\infty}$ & 2 ¿ & $\vec{\lambda}$ & \begin{tabular}{l|c}
$\tilde{N}$ & $\delta$
\end{tabular} & $\tilde{\sim}$ & ন \\
\hline 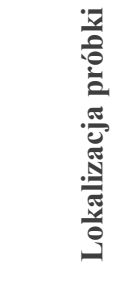 & & 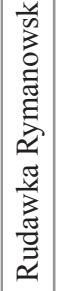 & 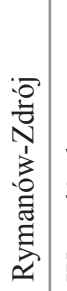 & 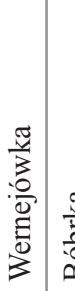 & 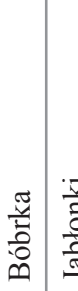 & 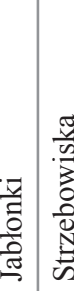 & 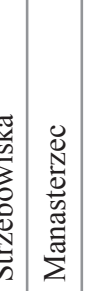 & 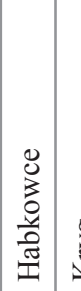 & 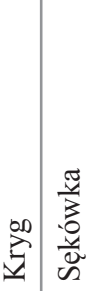 & $\mid \begin{array}{l}\frac{\pi}{3} \\
\frac{0}{0} \\
\frac{0}{2} \\
3 \\
3\end{array}$ & 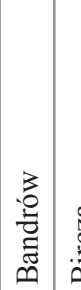 & 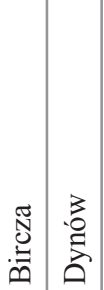 & 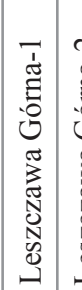 & 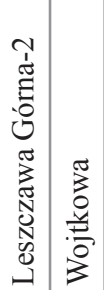 & 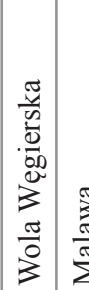 & 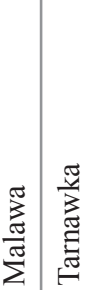 & $\begin{array}{l}\tilde{J} \\
\tilde{N} \\
\text { n. } \\
\sum\end{array}$ & 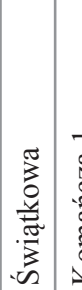 & 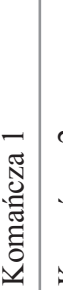 & \\
\hline 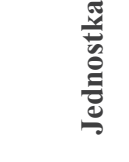 & & & & & & is & tis & & & & & & & $\begin{array}{l}\mathbb{v} \\
\tilde{n} \\
0 \\
\frac{1}{\omega}\end{array}$ & & & & - & & \\
\hline
\end{tabular}




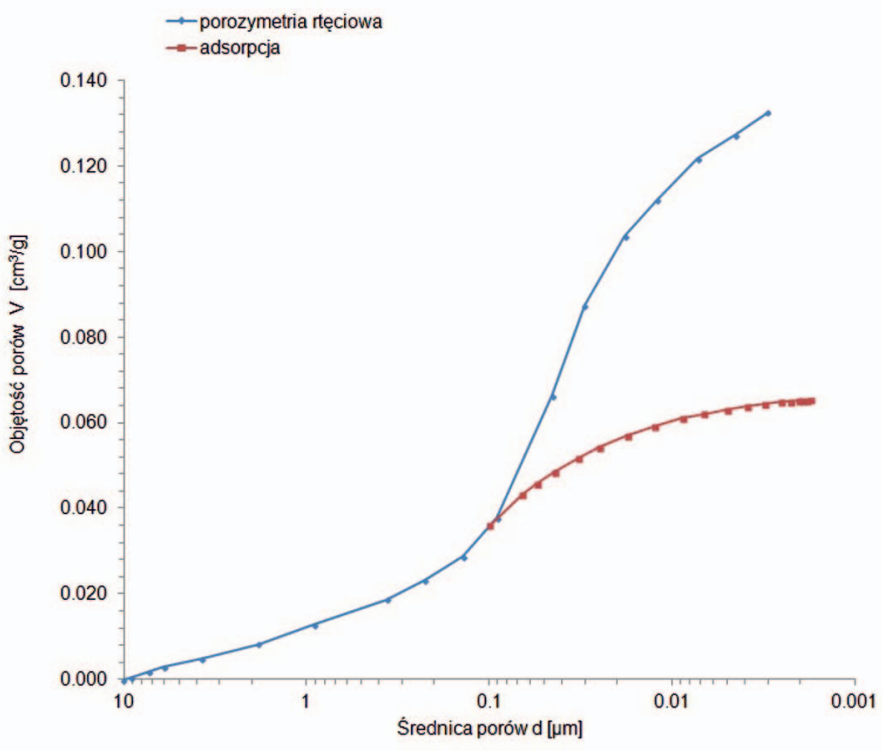

Rys. 1. Standardowe przedstawienie krzywej kumulacyjnej dla próbki 13

Fig. 1. Standard accumulation curve method for sample 13

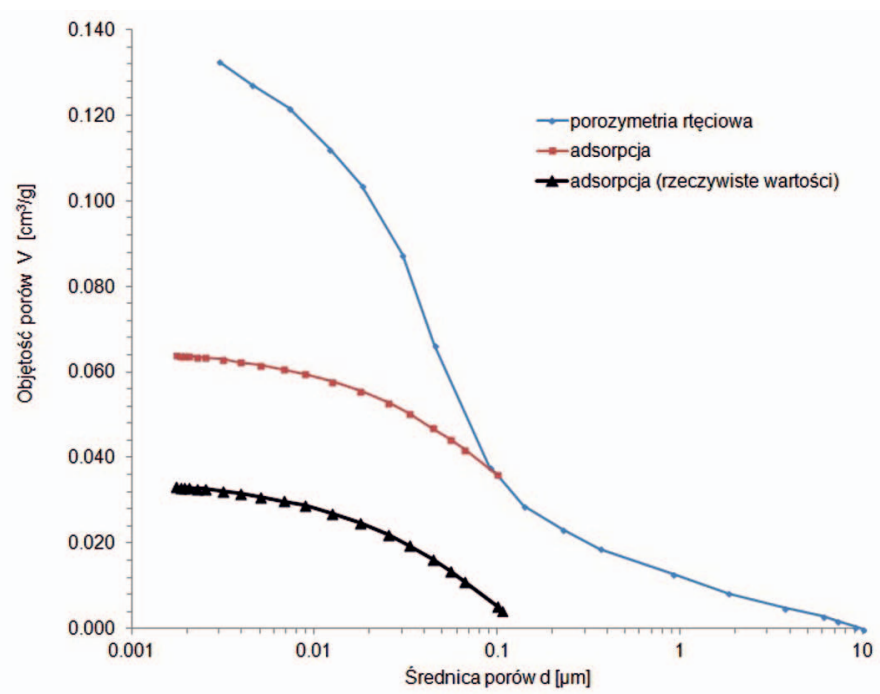

Rys. 2. Rosnąca oś rzędnych ze sztucznie transferowanymi danymi adsorpcyjnymi dla próbki 13

Fig. 2. Increasing ordinate axis with artificially transposed adsorption data for sample 13

W przedstawieniu w skali logarytmicznej na rysunku 3 oraz liniowym na rysunku 4 nie zastosowano żadnego sztucznego przesunięcia któregokolwiek z wykresów. Na rysunku 3 widać tzw. efekt brzegowy, którego występowanie jest skutkiem istnienia nierówności na ściankach badanej próbki i daje w rezultacie pozorny wzrost porowatości obliczanej z porozymetru w granicach $0,1-0,5 \%$. W przypadku próbek porowatych efekt ten jest zaniedbywany, a w przypadku małej porowatości jego wpływ staje się coraz większy (Labus, 1996). Niektórzy autorzy (Kuila i Prasad, 2013) dzielą otrzymane dane przez $d \log D$ celem zbliżenia danych rzeczywistych, tak aby można je było ze sobą łatwo porównać na skali liniowej. Dane na rysunkach 3 i 4 są danymi rzeczywistymi, a przedstawione na nich pola powierzchni są równe różnicowym objętościom porów mierzonym poprzez zaadsorbowany ciekły azot lub wypełnienie rtęcią pomiędzy dwiema średnicami pomiarowymi. Porównanie kątów nachylenia linii na rysunku 4 pozwala ponadto ocenić, czy pory pod wpływem ciśnień rtęci są ściskane, czy też rozrywane. Dla każdej struktury porowej w zakresie wybranych średnic porowych objętościowa ilość cieczy niezwilżającej wypełniającej te pory powinna być identyczna bez względu na użyty rodzaj cieczy (rtęć, ciekły azot, ciekły metan, ciekły argon itp.), a zaistniałe różnice pomiarowe są doskonałym źródłem informacji o właściwościach fizycznych i chemicznych tej struktury porowej. Również lokalne dominujące średnice są dobrze widoczne na rysunkach 3 i 4, a są nie do rozróżnienia na rysunkach 1 i 2 . Jedyną wartością uzyskiwaną z wykresów na rysunkach 1 i 2 jest całkowita, jak również różnicowa objętość porowa dla rtęci w przedziale $0,1-10 \mu \mathrm{m}$ oraz dla adsorpcji w przedziale $0,0017-0,1 \mu \mathrm{m}$.

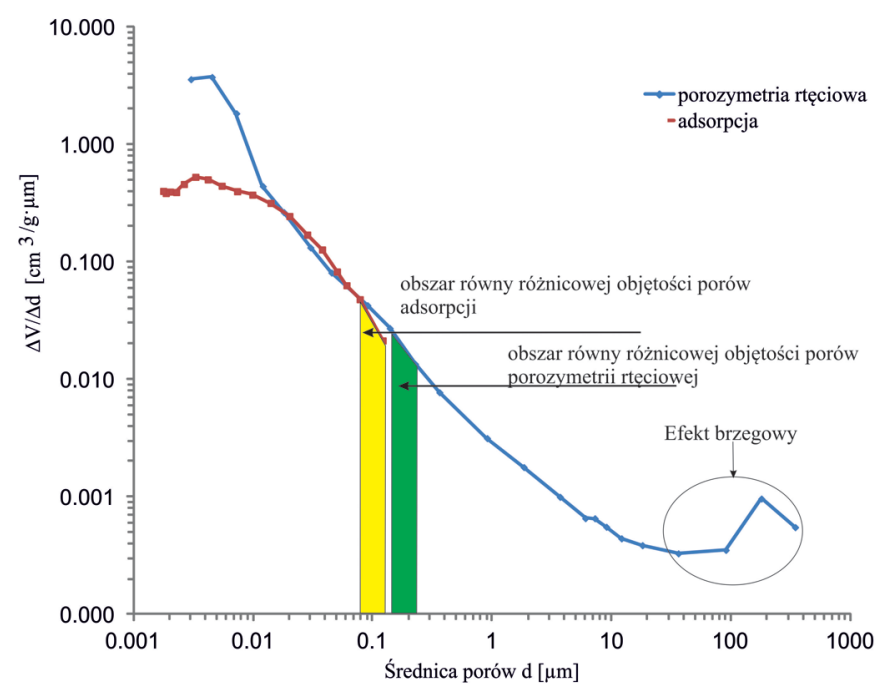

Rys. 3. Rzeczywiste nakładanie pochodnych

Fig. 3. Actual overlay of volumetric fractional derivatives

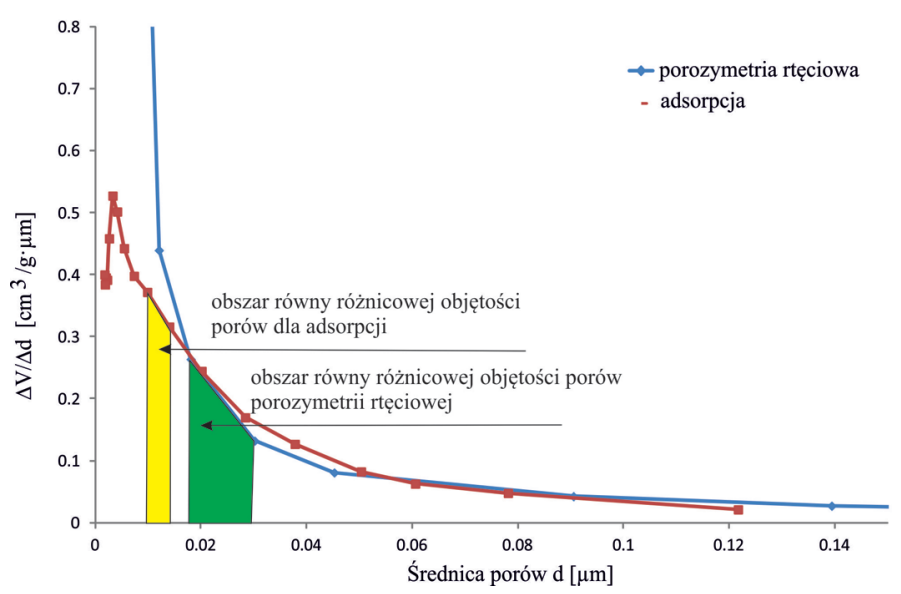

Rys. 4. Liniowe przedstawienie danych z rys. 3

Fig. 4. Linear data depiction from Fig. 3 
Jednakże wartości te można również otrzymać z sumowania pól powierzchni dla poszczególnych zakresów z rysunków 3 i 4.

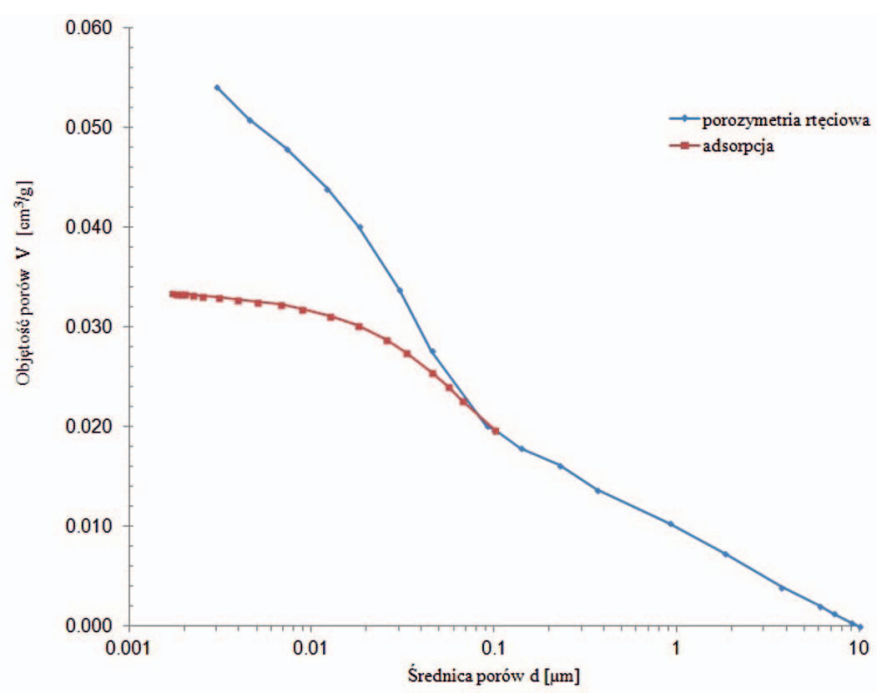

Rys. 5. Krzywe kumulacyjne próbki 12

Fig. 5. Accumulation curves for sample 12

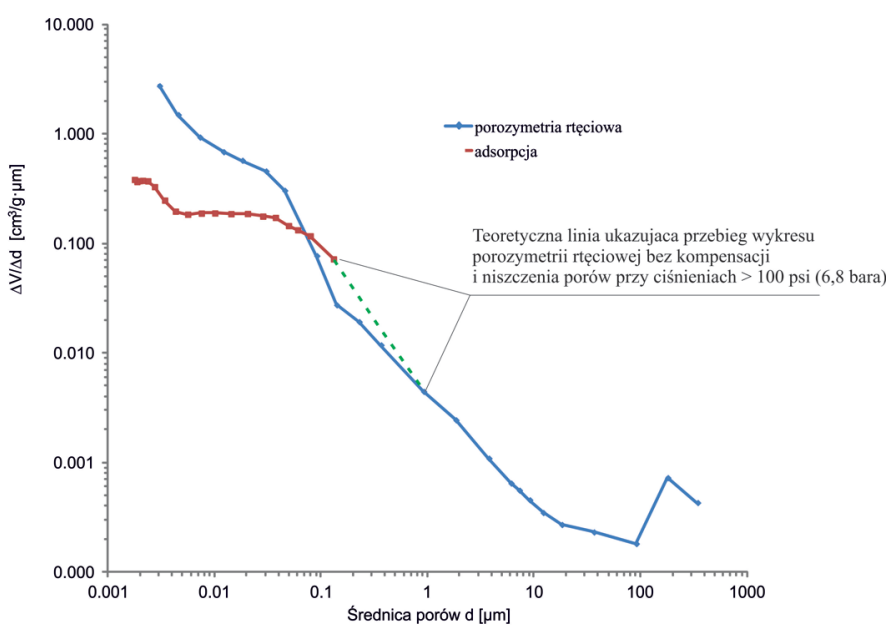

Rys. 6. Krzywe pochodnych próbki 12

Fig. 6. Fractional derivative curves for sample 12

Na przykładzie próbki 12 widać, że informacja zawarta w sztucznie przesuniętych krzywych kumulacyjnych na rysunku 5 jest stosunkowo ograniczona, lecz krzywa pochodnych tej próbki przedstawiona na rysunku 6 daje znacznie więcej informacji o przestrzeni porowej oraz typie materiału, z którego jest zbudowana próbka. Zaznaczona kolorem zielonym linia przerywana na rysunku 6 ukazuje, jak teoretycznie powinna przebiegać linia trendu porozymetrii rtęciowej do momentu połączenia się z krzywą adsorpcji. Wykres na rysunku 6 uwidacznia efekt ściskania porów przez rtęć od ciśnienia powyżej 100 psi aż do momentu przekroczenia dopuszczalnych naprężeń i niszczenia porów lub tylko ich wejść, tj. porów zamkniętych przy średnicy $140 \mathrm{~nm}$ (ciśnienie 1300 psi), gdyż dalsze wpływanie rtęci do porów i przyrost tego napełnienia (kąt pochylenia krzywych liniowych na rysunku 7) są prawie identyczne jak przyrost objętości porowej w adsorpcji, aż do średnicy $90 \mathrm{~nm}$ (ciśnienie 2000 psi). Kompensując krzywą adsorpcji o to ściśnięcie makroporów, konieczne jest przesunięcie wykresu porozymetrii rtęciowej o tę wartość, tak aby bardziej uważnie zaobserwować trendy różnic pomiędzy adsorpcją a porozymetrią rtęciową w interesującym zakresie, jak przestawiono to na rysunku 8 . Na wykresie na rysunku 8 wyraźnie widać, że przyrost pochodnej objętości (w przypadku porozymetrii rtęciowej) powyżej 2000 psi (<90 nm średnica porowa) wskazuje na niszczenie struktur porowych.

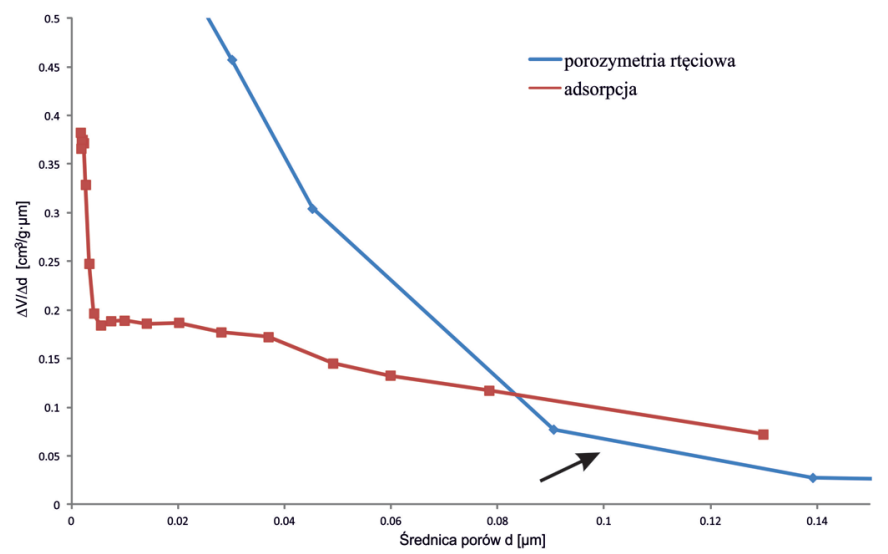

Rys. 7. Wybrany fragment pochodnej objętości względem średnicy dla próbki 12

Fig. 7. Selected fragment of volumetric fractional derivative versus pore diameter for sample 12

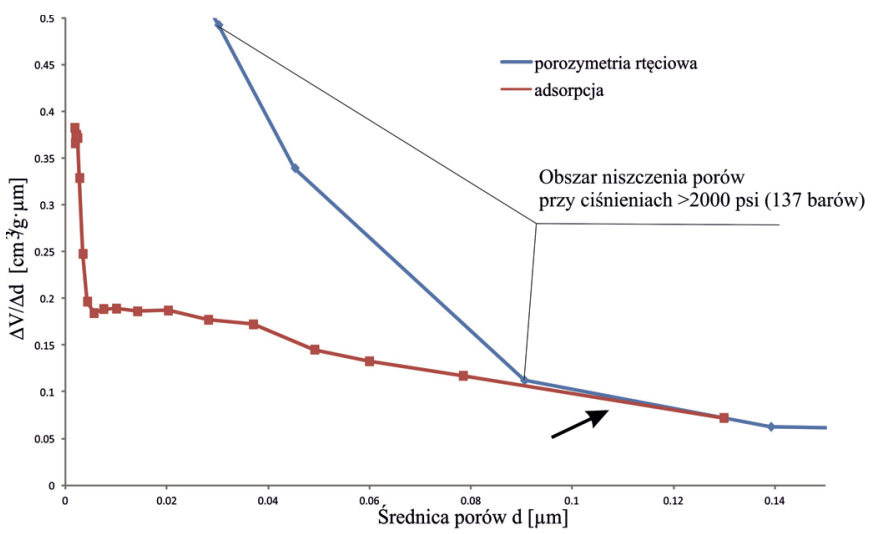

Rys. 8. Wybrany fragment pochodnej objętości względem średnicy po kompensacji makroporów dla próbki 12

Fig. 8. Selected fragment of volumetric fractional derivative after macro-pore compensation for sample 12

Ze wszystkich 24 przeanalizowanych próbek w przypadku $11 \mathrm{z}$ nich punkt początkowy pochodnej adsorpcji (przy średnicy porów $\sim 0,1 \mu \mathrm{m}$ ) leży poniżej odpowiedniego punktu pochodnej porozymetrii rtęciowej (tak jak na rys. 3), a w przypadku pozostałych 13 leży na krzywej porozymetrii rtęciowej lub powyżej tej krzywej (tak jak na rys. 6), co wskazuje na istnienie fizycznych zależności pomiędzy tymi dwoma pomiarami w tym układzie współrzędnych. 


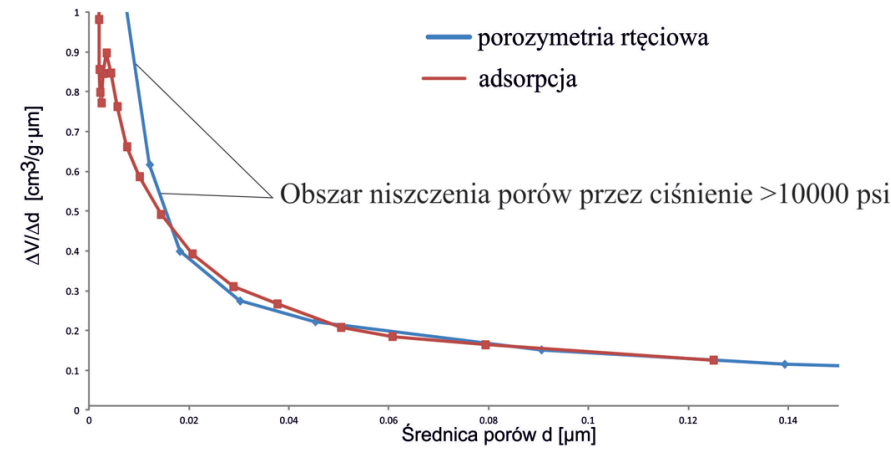

Rys. 9. Wybrany fragment pochodnej objętości względem średnicy dla próbki 9

Fig. 9. Selected fragment of volumetric fractional derivative versus pore diameter for sample 9

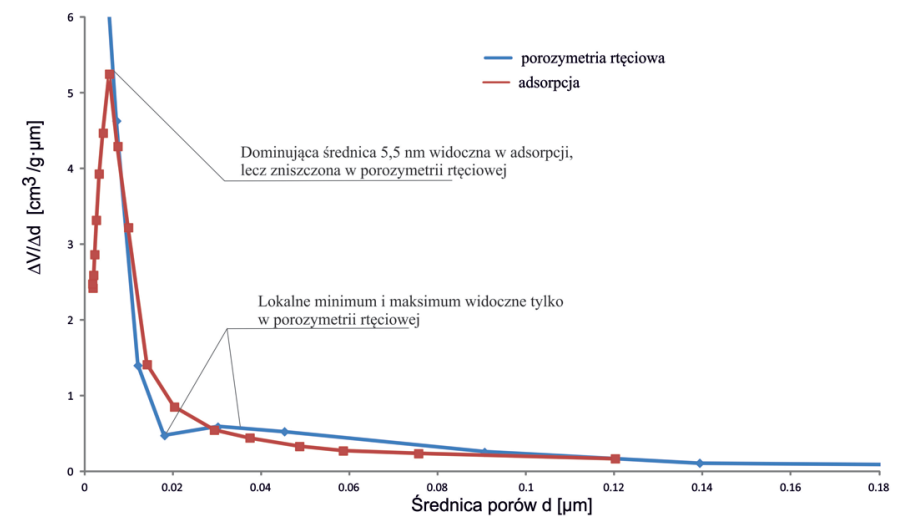

Rys. 10. Wybrany fragment pochodnej objętości względem średnicy dla próbki 14

Fig. 10. Selected fragment of volumetric fractional derivative versus pore diameter for sample 14 .

Rysunki 9-12 ukazują zgodność porozymetrii rtęciowej $\mathrm{z}$ adsorpcją dla dużych ciśnień rtęci, lecz pory tych próbek nie ulegają zniszczeniu - następuje to dopiero przy bardzo wysokich ciśnieniach.

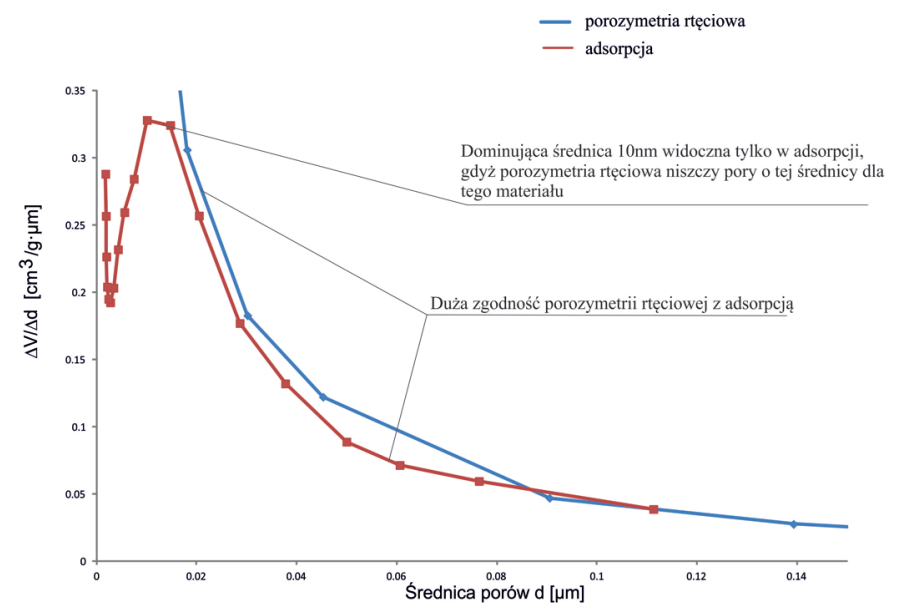

Rys. 11. Porównanie dla próbki 21

Fig. 11. Comparison for sample 21

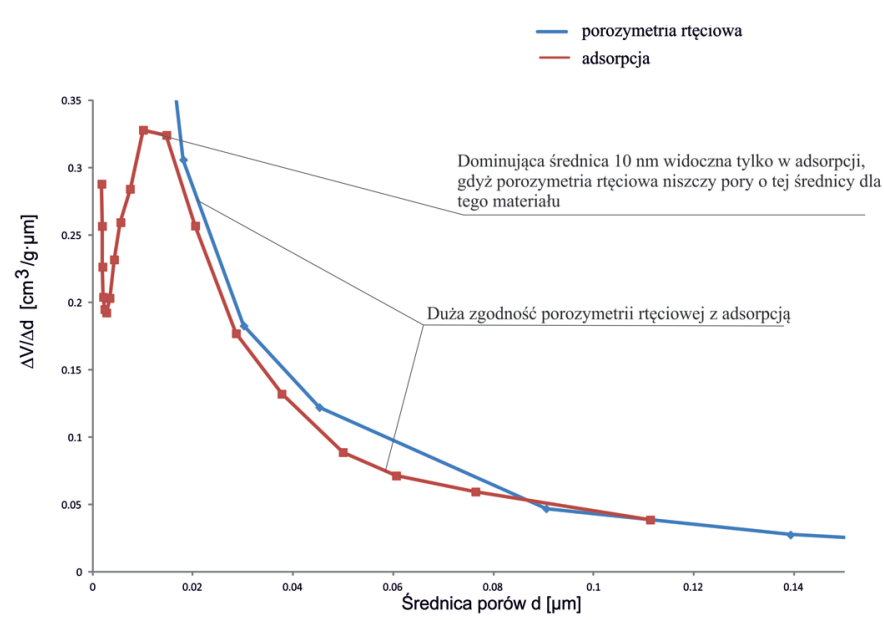

Rys. 12. Porównanie dla próbki 18

Fig. 12. Comparison for sample 18

Z analizy rysunków 9-12 wynika, że im większa wytrzymałość skały na rozciąganie i ściskanie, tym lepsza korelacja wyników porozymetrii rtęciowej z adsorpcją i tym mniejsza różnica w wartościach dominujących średnic porowych.

\section{Wnioski:}

1. Przedstawienie pochodnych $d V / d D$ porozymetrii rtęciowej oraz adsorpcji na jednym wykresie w dwóch skalach logarytmicznych daje znacznie więcej informacji odnośnie do przestrzeni porowych i ich dominujących średnic niż przedstawianie danych kumulacyjnych przesuniętych o sztucznie określoną wartość stosowane dotychczas.

2. Stosowanie pochodnych względem $d \log D$ służy tylko do zwiększenia wartości pochodnych przedstawionych na wykresie.

3. Wykres liniowy pochodnych $d V / d D$ względem średnicy porowej w zakresie krzywej adsorpcji pozwala na porównanie go $\mathrm{z}$ analogicznym wykresem w tym samym zakresie porozymetrii rtęciowej, a pola powierzchni poszczególnych segmentów są równe różnicowym wypełnieniom porów azotem lub rtęcią w danym zakresie.

4. Dzięki przedstawieniu pochodnych $d V / d D$ na wspólnym wykresie możliwe jest wyeliminowanie błędów związanych z pękaniem porów pod wpływem ciśnień oraz uniknięcie błędnej interpretacji porozymetrii rtęciowej dla kruchych skał, takich jak niektóre skały zawierające dużo kwarcu i skaleni.

5. Porównując wyniki metody adsorpcyjnej z wynikami porozymetrii rtęciowej, należy pamiętać o różnicach w zakresach obu technik badawczych oraz o tym, że azot i rtęć rejestrują struktury porowe w odmienny sposób. Metoda adsorpcyjna pozwala określać teksturę materiałów porowatych 
o rozmiarach porów od $200 \mathrm{~nm}$ do dziesiątych części nanometra, w zależności od adsorbowanego gazu. Porozymetria rtęciowa natomiast, polegająca na penetracji struktury porowatej badanego materiału, pozwala mierzyć rozmiary porów od kilku $\mu \mathrm{m}$ do około 3,6 nm przy ciśnieniu wtłaczania rtęci rzędu 60000 psi. Obie wartości są więc silnie zależne od zakresu ich wyznaczania i dostarczają różnych informacji.

6. Dla każdej struktury porowej w zakresie wybranych średnic porowych objętościowa ilość cieczy niezwilżającej wypełniającej te pory powinna być identyczna bez względu na użyty rodzaj cieczy (rtęć, ciekły azot, ciekły metan, ciekły argon itp.), a zaistniałe różnice pomiarowe są doskonałym źródłem informacji o właściwościach fizycznych i chemicznych tej struktury porowej.

7. Najwięcej najmniejszych porów $(0,01-0,005 \mu \mathrm{m})$ posiada próbka 20 z Tarnawki - 32,5\%, a najmniej próbka 8 z Habkowiec - 0,2\%. Najwięcej porów w zakresie 10-1,0 $\mu$ m posiada próbka 6 z rejonu Strzebowisk - 32,8\%, a najmniej próbka 3 z Wernejówki - 7,7\%. Największą porowatością otwartą, wynoszącą 48,26\%, charakteryzuje się próbka 18 z Woli Węgierskiej, ma więc najlepsze warunki transportu mediów złożowych. Najgorsze warunki transportu cechują próbkę $5 \mathrm{z}$ Jabłonek - porowatość otwarta wynosi 2,37\%.

8. Wartości powierzchni właściwej obliczonej metodą BET wahają się od $0,63 \mathrm{~m}^{2} / \mathrm{g}$ w rejonie Rudawki Rymanowskiej do $30,04 \mathrm{~m}^{2} / \mathrm{g}$ w rejonie Dynowa.

9. Wskazane byłoby wykonanie podobnych badań całego profilu wychodni warstw menilitowych z jednej lokalizacji w celu zbadania relacji pomiędzy zakresem zmienności uzyskanych wyników w skali lokalnej (odsłonięcia) a ujęciem regionalnym w odniesieniu do całej jednostki strukturalnej.

Artykuł powstał na podstawie pracy statutowej pt. Charakterystyka przestrzeni porowej warstw menilitowych na podstawie badań porozymetrii rtecciowej $i$ adsorpcji azotu - praca INiG - PIB na zlecenie MNiSW; nr zlecenia: 0050/KB/2019, nr archiwalny: DK-4100-0050/2018.

\section{Literatura}

Barrett E.P., Joyner L.S. Halenda P.P., 1951. The determination of pore volume and area distribution in porous substances. I. Computations from nitrogen isotherms. J. Am. Chem. Soc., 73: 373-380. DOI: 10.1021/ja01151a046.

Brunauer S., Emmett P.H., Teller E., 1938. Gas In Multimolecular Layers. J. Am. Chem. Soc., 60: 309-319. DOI: 10.1021/ ja01269a023.

Cicha-Szot R., Dudek L., Such P., 2015. Charakterystyka fraktalna przestrzeni porowej skał łupkowych. Przemyst Chemiczny, 94(12): 1000-1007. DOI: 10.15199/62.2015.12.39.

Dudek L., 2016. Rozkłady wielkości porów w złożach typu shale gas na podstawie analiz izoterm adsorpcji. Nafta-Gaz, 8: 603-609. DOI: $10.18668 /$ NG.2016.08.03.

Dudek L., 2019. Wpływ zmian temperatury i czasu wygrzewania próbek skał mułowców na rozkład wielkości porów i powierzchnię właściwą BET na podstawie analiz izoterm adsorpcji. Nafta-Gaz, 1: 10-16. DOI: 10.18668/NG.2019.01.02.

Faass G., 1981. Correlation of gas adsorption, mercury intrusion and electron microscopy pore property data for porous glasses. Georgia Institute of Technology.

Halsey G., 1948. Physical adsorption on non-uniform surfaces. J. Chem Phys., 16: 931-937. DOI: 10.1063/1.1746689.

Kuila U., Prasad M., 2013. Specific surface area and pore-size distribution in clays and shales. Geophysical Prospecting, 61: 341-362. DOI: 10.1111/1365-2478.12028.

Labus M., 1996. Związek między porowatością a stanem zachowania materiału kamiennego wybranych budowli zabytkowych na Górnym Śląsku. Przeglad Geologiczny, 44: 55-58.

Such P., Leśniak G., Mroczkowska-Szerszeń M., Dudek L., CichaSzot R., Spunda K., 2017. Metodyka analizy przestrzeni porowej skał łupkowych. Prace Naukowe Instytutu Nafty $i$ GazuPaństwowego Instytutu Badawczego, 214: 81-86. DOI: 10.18668/ PN2017.214.

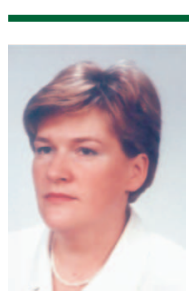

Mgr inż. Lidia DUDEK

Starszy specjalista badawczo-techniczny w Zakładzie Geologii i Geochemii Instytut Nafty i Gazu - Państwowy Instytut Badawczy ul. Lubicz $25 \mathrm{~A}$

31-503 Kraków

E-mail: lidia.dudek@inig.pl 